\title{
ENVIRONMENTAL AND SOCIO-ECONOMIC IMPACTS OF PHOTOVOLTAIC PARKS IN THE CENTRE DEVELOPMENT REGION. ROMANIA
}

DOI: http://dx.doi.org/10.18509/GBP.2020.84

UDC: 621.311.243:502.131.1(498)

\author{
Alexandra Vrînceanu \\ Monica Dumitrașcu \\ Irena Mocanu \\ Ines Grigorescu \\ Paul Șerban \\ Bianca Mitrică \\ Cristina Dumitrică \\ Institute of Geography, Romanian Academy, Bucharest - Romania
}

\begin{abstract}
Increasing the share of renewable energy has become one of the key actions Romania has assumed under the Europe 2020 strategy targets on climate change and energy (a.k.a. European 20-20-20 targets). Romania benefits from a wide variety of renewable energy sources (RES) - wind, solar, hydro, geothermal and biomass. Among the RES types, solar resources have started to significantly contribute to the electricity mix. Thus, under the rapid transformation and growth of the renewable energy sector, understanding the impacts of Photovoltaic (PV) parks is essential to avoid the potential negative consequences. Hence, the current study is seeking to assess the environmental and socioeconomic impacts of PV parks in Centre Development Region (CDR). The region is located in the central part of Romania covering $14.3 \%$ of the country's surface and holding nearly $12 \%$ of its population. It corresponds to the central and southern part of the Transylvanian Depression and the surrounding frame of the Carpathian Mountains. The evaluation relies on several environmental and socio-economic indicators. E.g. share of PV parks/land use category /main soil type; distance to forests, waters, Natura 2000; no. of jobs created during the construction/operation of the PV parks; the value of PV parks investment; the impact on the local budget. For the current assessment, $44 \mathrm{PV}$ parks were identified and mapped covering a total area of 415 ha.
\end{abstract}

Keywords: solar energy; photovoltaic (PV) parks; environmental impact; Centre Development Region (CDR), Romania

\section{INTRODUCTION}

Electricity is used in all fields of activity, from agriculture, to industry and services, thus supporting economic development. At the same time, energy is important for the population, since it guarantees its wellbeing. Due to the multiple use of electricity, the demand is constantly increasing. For energy supply, researchers are looking for solutions to streamline the use of resources but also new ways to obtain energy from renewable resources. Geographers not only relate the complex process of low-carbon energy transition offering concepts which allow us to assess the territorial impacts (location, territoriality, unequal development, and the scale/level concept) [1], but also, they assess the geographical process, involving the reconfiguration of the present patterns of 
economic and social activities [2]. Although up to now renewable energy has been recognized more for its environmental and socio-economic benefits, in the recent scientific literature there is a growing interest in evaluating the potential negative impacts $[3,4]$. To cope with the risk of a negative impact, a series of studies and models on electricity generation using solar energy have been carried out [5,6]. Each method of energy generation and transmission affects the environment [7]. Clearly, conventional generation options can damage air, climate, water, soil, wildlife, landscape, and increase the level of harmful radiation. Renewable technologies are substantially safer, offering a solution to many environmental and social problems associated with fossil and nuclear fuels $[8,9]$.

Solar energy technologies (TES) offer visible environmental benefits compared to conventional energy sources, thus contributing to the sustainable development of human activities. Regardless of the depletion of natural resources, their main advantage is related to the low $\mathrm{CO}_{2}$ emissions. The use of TES have additional positive implications to the environment in terms of: reducing greenhouse gas emissions (especially $\mathrm{CO}_{2}, \mathrm{NO}_{\mathrm{x}}$ ), preventing toxic gas emissions ( $\mathrm{SO}_{2}$, particles), recovering degraded land, reducing the transmission lines needed for electricity networks; improving the quality of water resources [10]. The socio-economic implications include: increasing the regional/national energy independence; providing significant employment opportunities; diversification and security of energy supply; supporting deregulation of energy markets [7].

The transition to renewable energy sources is imperative to achieve global carbon reductions and ensure future energy security. Only one technology, photovoltaic (PV), has begun to make a significant contribution to the electricity mix in many countries. In some cases, it has taken the form of large solar farms. The generation of photovoltaic energy implies an impact on the ecosystems (applicable to large photovoltaic farms) through the use of toxic and flammable materials (during module construction), reduced health risks from manufacture, use and dismantling [7].

One of the first studies focused on the assessment of the potential impact of solar energy was developed by [11]. In that paper, the author highlighted some important relationships between the implementation of photovoltaic (PV) technology and the consequences for the safety and health of people. Particular emphasis was placed on the indirect effects on the labour market, as well as on the environmental consequences. In this regard, land use, thermal and climate effects and emissions have been identified as relevant issues to be evaluated. In [12], a balance of the positive and negative impact of photovoltaic solar energy was defined by classifying the consequences into different classes: (i) land use and landscape, (ii) infrastructure, (iii) politics, (iv) energy market, (v) industry, research and development, education and (vi) public \& marketing. More information about large PV farms was given in [13]. The author described how photovoltaic systems can lead to a high level of sustainability, compared to traditional energy sources, for both construction and exploitation phases. The harmful effect could be highlighted for some wild animal species. [14] stressed the risk of photovoltaic panels on the use of fertile areas or the impact of technical equipment on the landscape. The public perception of photovoltaic systems was investigated by [15] in Greece. [16] investigated the public acceptance of photovoltaic solar energy in Spain through the role played by the media. The impact on land use and natural ecosystems depends on specific factors, such as landscape topography, the area covered by the photovoltaic systems, the type of land, the distance from the natural areas or the sensitive ecosystems regarding the change of biodiversity. The impact on the landscape is likely to evolve during construction through 
activities such as land levelling and transportation [7]. Moreover, applying a photovoltaic system on arable land might decrease soil productivity $[17,18,19,20]$. In Romania, most of studies on solar energy generally referred to climate parameters (i.e. solar radation) necessary in assessing its potential [21,22,23,24], economic efficiency [25,26] or policy context [27] for its valorisation. Recently, some regional studies have focused on the environmental and socio-economic impacts of PV farms [28,29].

Increasing the share of renewable energy is essential to achieving the EU's climate and energy goals, namely to reach $20 \%$ of its energy from renewable sources by 2020 and at least $32 \%$ by 2030 . However, Romania has already reached the 2020 targets and undertakes measures to achieve the new target for 2030 in accordance to the provisions of the Energy Strategy of Romania for the period 2007-2020 and of the Energy Strategy of the Romania 2016-2030 with the perspective of 2050 [28,29]. Currently, the total installed capacity of electricity is $19 \mathrm{GW}$, to increase to $22 \mathrm{GW}$ in 2025 and to $25 \mathrm{GW}$ in 2030, according to the estimates of the Integrated National Plan in the field of Energy and Climate Change 2021-2030 (PNIESC). At the same time, the projections for the year 2030 foresee an increase of photovoltaic capacities of up to about $5 \mathrm{GW}$, from $1.4 \mathrm{GW}$ at present. This increase is estimated to be in line with the following plan (PNIESC): +994 MW additional installed capacity in 2022 compared to $2020 ;+1,037$ MW additional installed capacity in 2025 compared to $2022 ;+528 \mathrm{MW}$ additional installed capacity in 2027 compared to $2025 ;+1,133$ MW additional installed capacity in 2030 compared to 2027.

In Romania, it is estimated that, in the coming years, photovoltaic capacities will be developed both in the form of medium-capacity solar parks, realized on degraded or poorly productive lands, as well as in small, dispersed capacities, achieved by the energy consumers who can make the transition to the prosumer (PNIESC).

In this context, the authors are seeking to exemplify, at a regional scale (i.e. Centre Development Region), the environmental and socio-economic consequences of PV farms focusing on the following main objectives: (1) identifying and mapping all PV farms in Centre Development Region (CDR); (2) assessing the main environmental (on soils, forests, roads, settlements) and (3) socio-economic (e.g. land use/cover, no. of jobs created during the construction/operation; the value of investment) impacts of PV farms based on relevant indicators, as well as on questionnaires surveys and interviews.

\section{STUDY AREA}

The region is located in the centre part of Romania covering $14.3 \%$ of the country's surface and holding nearly $12 \%$ of its population. From administrative point of view, it includes 6 counties (Alba, Braşov, Covasna, Harghita, Mureş and Sibiu) which are among the most economically developed at national level. It corresponds to the central and southern part of the Transylvanian Depression and the surrounding frame of the Carpathian Mountains (Apuseni Mountains to the West, Eastern Carpathians to the East and South-East and Southern Carpathians to the South). In relation to the variety of relief forms, it displays various climatic and biopedological conditions with alpine, subalpine and forest floors. The climate is temperate with oceanic influences and with relatively abundant precipitation. Due to the orographic dam of the Carpathians, a topoclimate of shelter prevails, with a high share of atmospheric calm (30-60\%) [30] and relatively high sunshine duration values [31]. In addition, the predominance of sunny and semi-sunny slopes (over 55\%) also supports sunshine values of up to 2000-2100 hours that can be exploited as alternative energy source (Fig. 1). As a result, between 2012 and 2017, 44 
photovoltaic parks were built, with areas between 0.45 ha and 109 ha, unevenly distributed according to different indicators, such as the sunshine duration, the relief and land use/cover. Brașov County concentrates the largest number of photovoltaic panels (34\%), followed by Mureș (30\%), Sibiu (23\%), Covasna (7\%), Alba (5\%) and Harghita (2\%) Counties.
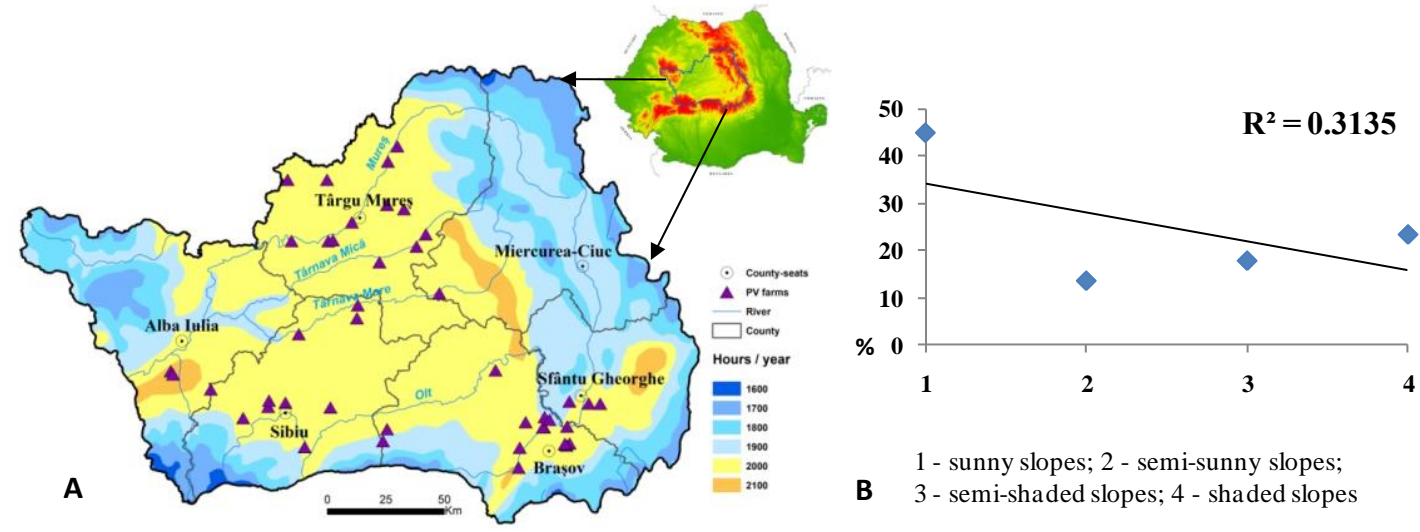

Figure 1. Sunshine duration (A) and slopes exposure in CDR

Although the region concentrates $15 \%$ of the photovoltaic parks in Romania (the third after South and North-West Development Regions), the sunshine duration is not the main driving factor of their set-up. However, other factors that sustain and explain the development of PV parks in the study area (e.g. land use/cover, slope exposure, land price, the legislative context). Two main areas with PV parks were identified: the Transylvanian Depression and Brașov Depression (Eastern Carpathians) (Fig. 2A). Of these, the Transylvanian Depression offers the best conditions for PV parks location with over $60 \%$. The surfaces vary between 0.45 ha in Sibiu County and 109 ha in Brașov County, occupying a total area of 415.3 ha. Most PV parks are located in Braşov County, but over $65 \%$ of them have surfaces under 10 ha; $84 \%$ of the PV parks have areas under 10 ha, and only $4.5 \%$ are larger than 50 ha (Fig. 2B).
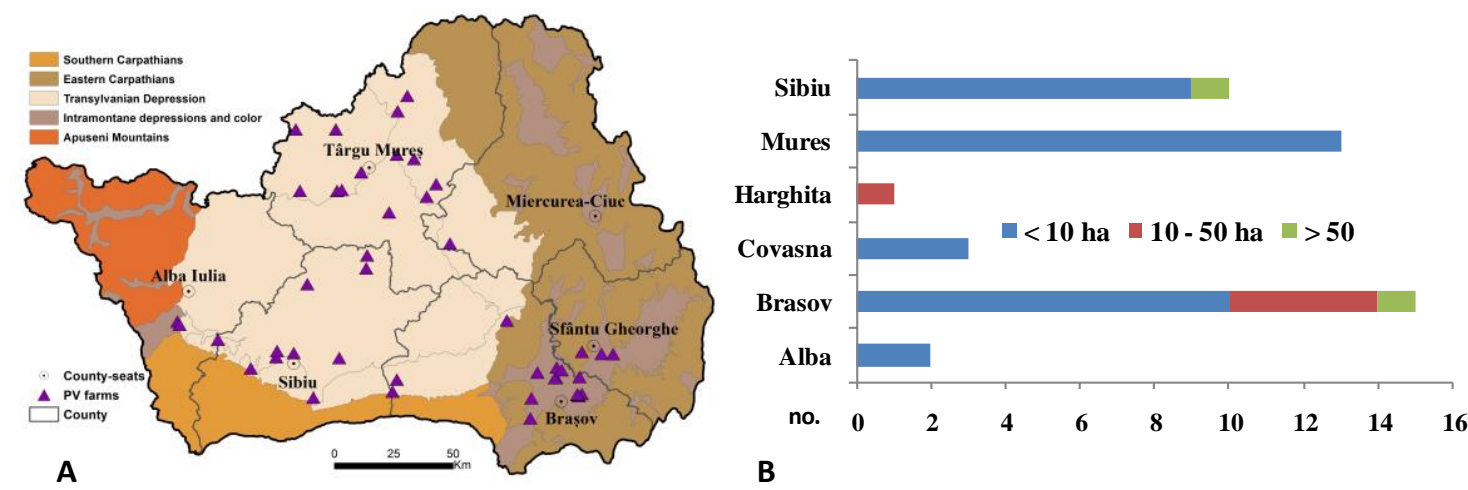

Figure 2. PV parks distribution on relief units (A) and distribution and surfaces at county level

\section{DATA SOURCES AND METHODS}

Under the rapid transformation and growth of the renewable energy sector, understanding the impacts of Photovoltaic (PV) parks is essential for preventing the potential negative environmental and socio-economic consequences [7,12,28,29,32] Hence, the current study is seeking to assess the impacts of PV farms in CDR, a region with significant 
conventional energy resources (it holds the highest reserves of natural gas in the country) which is trying to move towards greener energy sources. The authors made use of spatial and statistical data, but also information from field investigations (questionnaire surveys and interviews) in order to combine quantitative and qualitative information for a more accurate assessment.

The first stage was mapping the PV parks which was done using the satellite images (Landsat 7 ETM and Landsat 8 OLI, 2018) and the records provided by the Romanian Transmission and System Operator (TSO) Transelectrica (e.g. installed power of each PV park, type of PV).

The second stage was to highlight the impacts of PV farms on the environment based on a several statistical and spatial indicators [28,29]: the share/surface of PV farms at Local Administrative Unit (LAU) level; the share of PV farms of each land use/cover category (based on CORINE Land Cover 2012 and 2018); distance to forests, waters, protected areas (SCI, SPA); share of PV farms of main soil types. Based on the resulted statistics, the authors were able to identify the existing and the potential environmental impacts of solar systems on specific environmental components.

The third stage was to assess the socio-economic impact in relation to the setting-up and function of photovoltaic farms in the CDR. For this approach, several data sources and methods were used, imposed by the diversity of the social and economic effects of solar projects: county and local (e.g. County Statistics Offices, County Environment Protection Agency, and mayoralties) and national (e.g. National Institute of Statistics and the National Regulatory Authority for Energy) institutions. The great number of photovoltaic farms (44 PV parks), the large scale of analysis (6 counties with different natural and socio-economic backgrounds and diverse opportunities for investments and development of the renewable energy industry, photovoltaic energy industry in particular), and the regional and local specificities impose the need to complete the official and statistical data by field investigations (carried out in the summer 2019). They were carried out in the rural settlements where several categories of PV farms (in terms of size) were set-up: very large and large (30 to 110 ha), medium (10 to 29 ha) and small (under 10 ha). Thus, the field investigations were carried out in Ucea de Sus (Brașov County) and Miercurea Sibiului (Sibiu County) for the first category, in Hoghiz and Hălchiu (Brașov County) for the second category and in Ernei and Cuci (Mureș County) for the last category. During the field investigations, a number of 24 interviews were conducted with the representatives of the six mayoralties (mayors, local councilors in the fields of urbanism, local economic and sustainable development). The interviews were focused on four issues: (i) land use/cover changes, (ii) investments \& new created jobs and (iii) consequences for the local budget (types of taxes).

\section{RESULTS AND DISCUSSIONS}

PV farms could cause direct or indirect negative implications to the environment ever since their installation to operation and then decommission [7,32] affecting almost all environmental components (e.g. soils, forests, waters), also in relation to the proximity to certain supporting infrastructure (i.e. roads) or settlements. Generally, PV parks are located on productive agricultural land with fertile soils. It is also the case of CDR, where $50 \%$ of the PV parks have replaced high fertility soils, such as molisols and alluvial soils, especially in Brașov and Sibiu Counties. However, over 25\% of PV parks are built on low productivity land, especially in Mureș and Sibiu Counties (Fig. 3), which is 
pinpointing a sustainable way of attributing economic value to lands with less productivity.
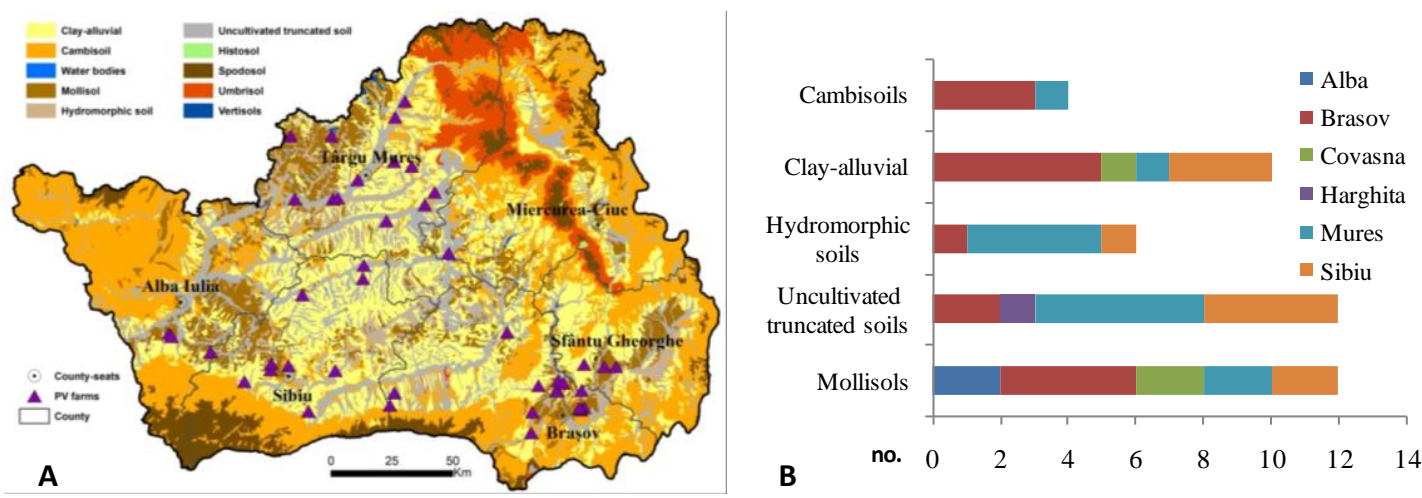

Figure 3. PV parks distribution on main soil types in CDR (A) and at county level (B)

Given that the region is rich in water resources, most PV parks $(68 \%)$ are located less than $1 \mathrm{~km}$ from the hydrographic network, and $84 \%$ are at less than $2 \mathrm{~km}$. However, this could draw several environmental consequences due to the thermal discharges or accidental discharges of chemicals used to clean the panels [28,29,32]. At county level, Sibiu, Brașov and Mureș Counties concentrate $61 \%$ of the photovoltaic panels that are less than $1 \mathrm{~km}$ away from a water body (Fig. 4).
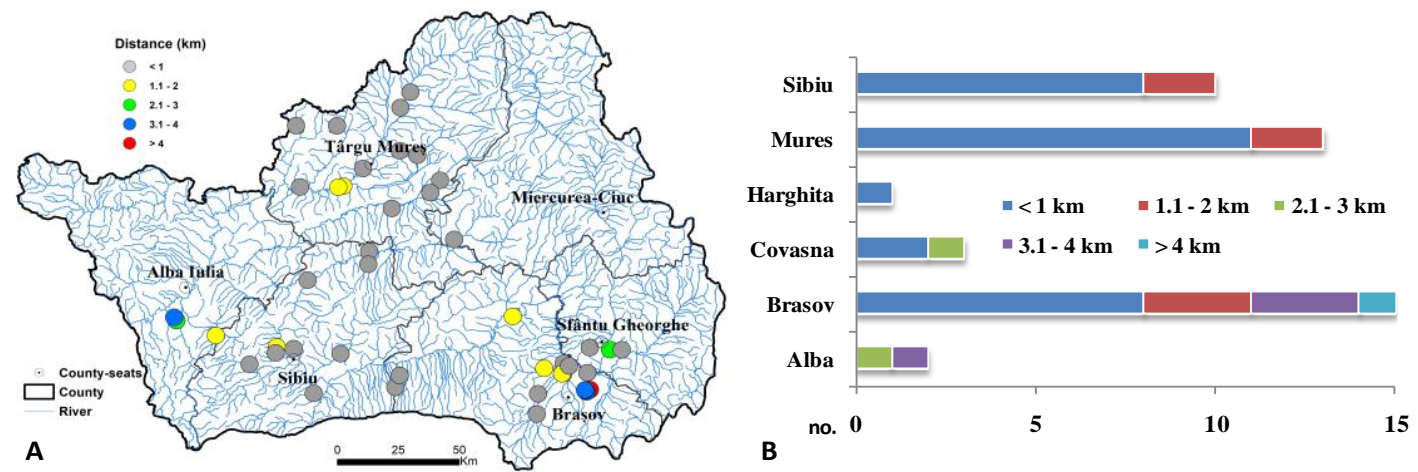

Figure 4. Distance of PV parks to water bodies in CDR (A) and at county level (B)

Over $60 \%$ of the photovoltaic parks were built at distances of over $1 \mathrm{~km}$ from the protected natural areas (Natura 2000 sites) and over $45 \%$ of them at more than $2 \mathrm{~km}$ (Fig. $5)$. In 2013, the counties in which the panels were placed in the perimeter of the protected areas are Mureș (37\%), Sibiu (25\%), Brașov (25\%) and Covasna (13\%), but over time, the distance increased, reaching $9 \mathrm{~km}$ in Brașov, in 2014. This proves a continuous propensity to respect certain distances to protected areas aimed at minimizing impacts on ecosystems and habitats. 


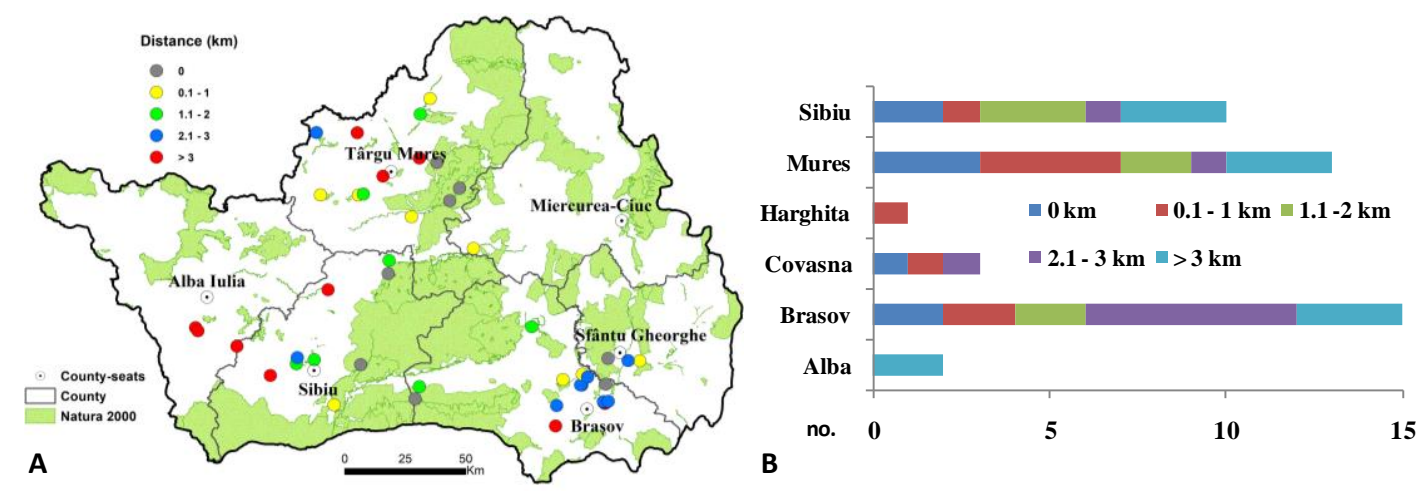

Figure 5. Distance of PV parks to Natura 2000 sites in CDR (A) and at county level (B)

In $\mathrm{CDB}$, taking into account the large coverage with woodland (48.4\%), $41 \%$ of the photovoltaic plants are located at a distance of less than $1 \mathrm{~km}$ and $75 \%$ at a distance of less than $2 \mathrm{~km}$ to forests (Fig. 6). The county with most panels built at a distance of less than $1 \mathrm{~km}$ from the nearest forest is Mures $(50 \%)$. This is increasing the potential of forest ecosystems of being affected by the solar systems throughout their entire development: installation, valorisation, maintenance, repairing services.
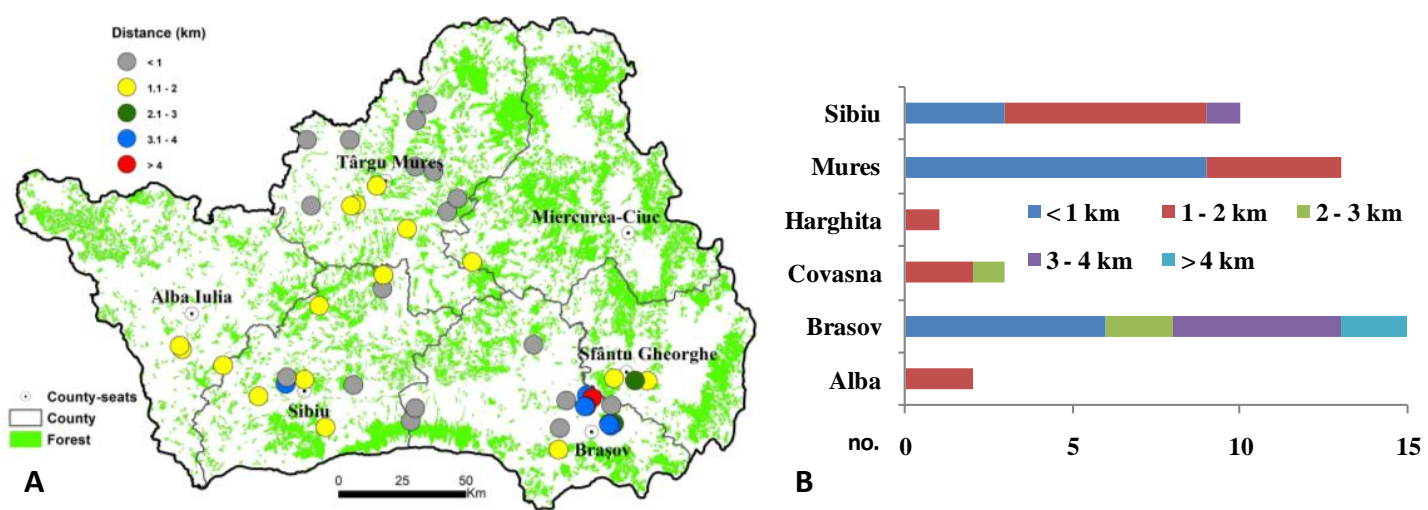

Figure 6. Distance of PV parks to forests in CDR (A) and at county level (B)

An important role in setting-up and exploiting PV parks is played by the supporting infrastructure (i.e. roads) and settlements. Thus, distance to roads is important since having a road nearby it enables the access to PV parks, but it can also lead to landscape and habitats fragmentation through the access of the necessary materials or substances for the PV installations into different environments, thus generating the negative impacts $[28,29]$. In CDR, most of the PV parks were built at a distance of less than $500 \mathrm{~m}$ from access roads, and $73 \%$ at a distance of less than $1 \mathrm{~km}$. At the county level, most PV parks located near access roads are in Sibiu and Mureș Counties favoured by the relief configuration and land use/cover (Fig. 7). 


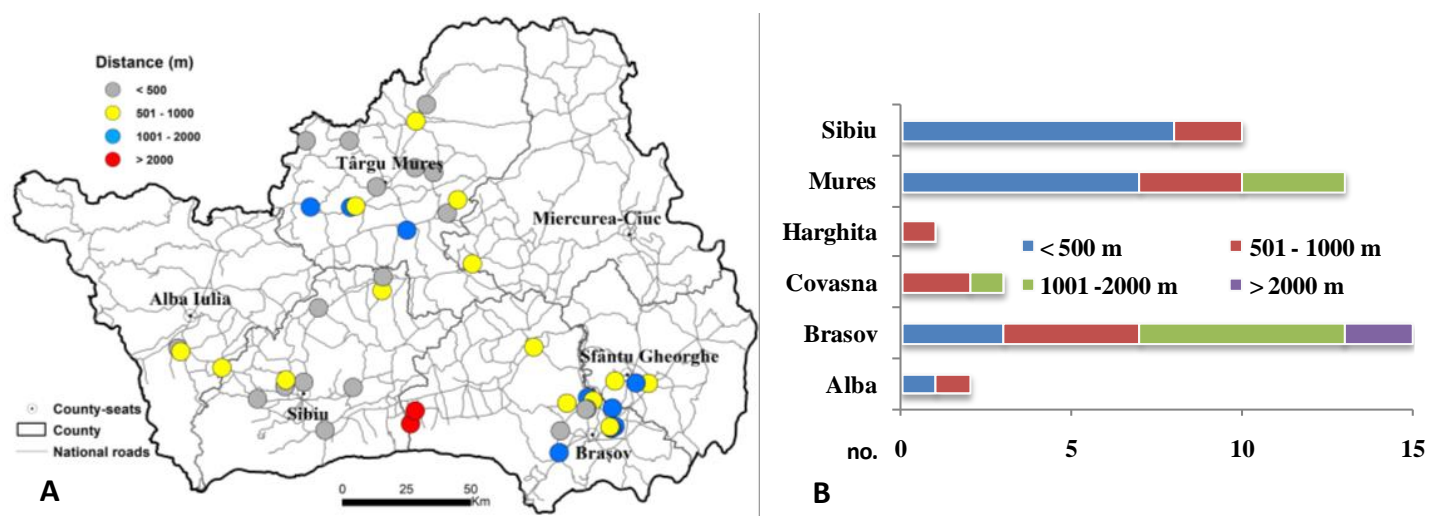

Figure 7. Distance of PV parks to national roads in CDR (A) and at county level (B)

The proximity to settlements generally has positive aspects; the closer the PV parks are to the localities, the less is the impact caused by the transport of construction materials on the environmental components. Over $35 \%$ of the PV parks are located at a distance of less than $500 \mathrm{~m}$ from a locality, and over $25 \%$ are positioned at more than $2 \mathrm{~km}$ from a settlement, closely related to the relief configuration. At the county level, in Sibiu and Mureș Counties, $30 \%$ of the power stations are located at less than $500 \mathrm{~m}$ from a settlement. In Braşov County, the rough relief caused most PV parks (67\%) to be built more than $1 \mathrm{~km}$ away from any settlement (Fig. 8).
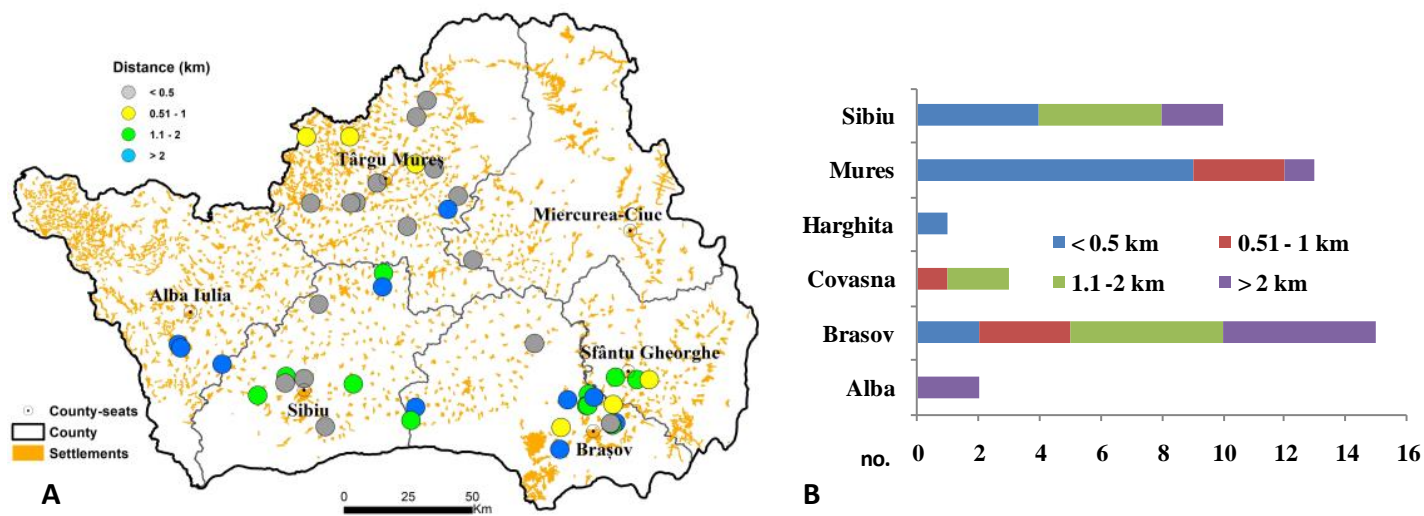

Figure 8. Distance of PV parks to settlements in CDR (A) and at county level (B)

Field investigations have shown that the main socio-economic effects of the PV parks implementation in the selected six rural LAU could be summed up as: investments in local rural economies, land/cover changes and the loss of farmland; very few jobs opportunities and positive effects on the local budget.

Investments in local rural economies (the available data was for only 34 photovoltaic farms in the study area). In CDR, the total investments rise up to nearly 267 mil. Euro, topped by Brașov and Mureș Counties followed by Sibiu County (a large number of PV parks with small and very small investments).

In Brașov and Sibiu Counties, the PV farms (in Miercurea Sibiului and Hoghiz communes) cumulated a total of 63 mil. Euro. Only in Brașov County very large PV farms were set-up (e.g. Ucea, 82.5 mil. Euro) (Fig. 9). Generally, there is a correlation between the investment and surface; thus for a $1 \mathrm{MW}$ an investment of $1.5 \mathrm{mil}$. Euro being necessary. The large and very large investments in PV parks in the study areas (Ucea and Miercurea Sibiului) are assumed by Chinese investors. As reveled by the field 
investigations, there are also Japanese (in Hoghiz), Portuguese (in Hălchiu), as well as Romanian (in Cuci and Ernei) investors. The latter hold smaller investments.
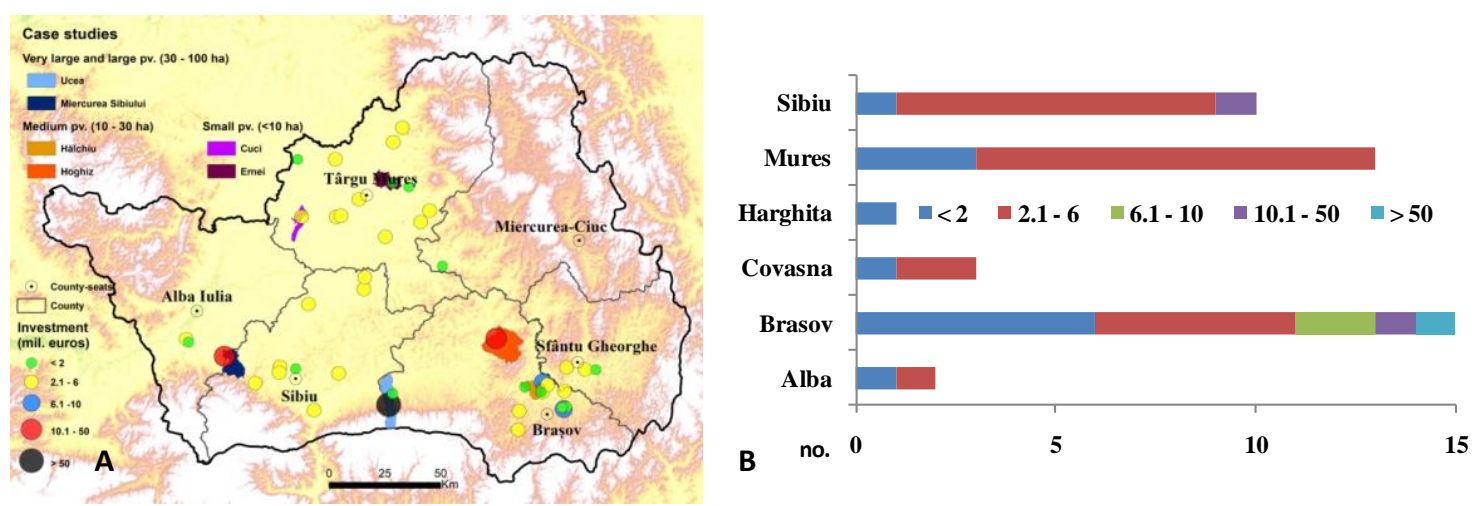

Figure 9. The investments in PV parks in CDR (A) and at County level (B)

Land use/cover changes and loss of farmland. The impact of PV farms on land use/cover $(L U C)$ depends on topography, the surface area they cover, or the land use type in relation to land transformation (land use change) and land occupation (land use for a certain period) $[28,29]$. In CDR, PV parks were mostly built on non-irrigated arable land (59\%), of which Bodogaia and Hărman covering the largest areas, 16 ha and 11.6 ha respectively, but also on pastures (7 parks, of which Ucea - 126 ha is the largest), artificial surfaces (6 parks, of which Miercurea Sibiului with 58.71 ha, and Hoghiz with 27.34 ha) or complex cultivation patterns ( 5 smaller parks, such as Dumbrăveni with almost 6 ha and Șura Mică, with 5.5 ha) (Fig. 10). Setting-up PV parks on agricultural land (i.e. arable land and complex cultivating patterns) will affect land productivity through the extraction of valuable arable land from cultivation, ultimately resulting in soil degradation and crop yields decline. However, using artificial surfaces to build PV parks might involve the reuse of abandoned industrial or commercial built environment, which could be turned into a positive land use transition.
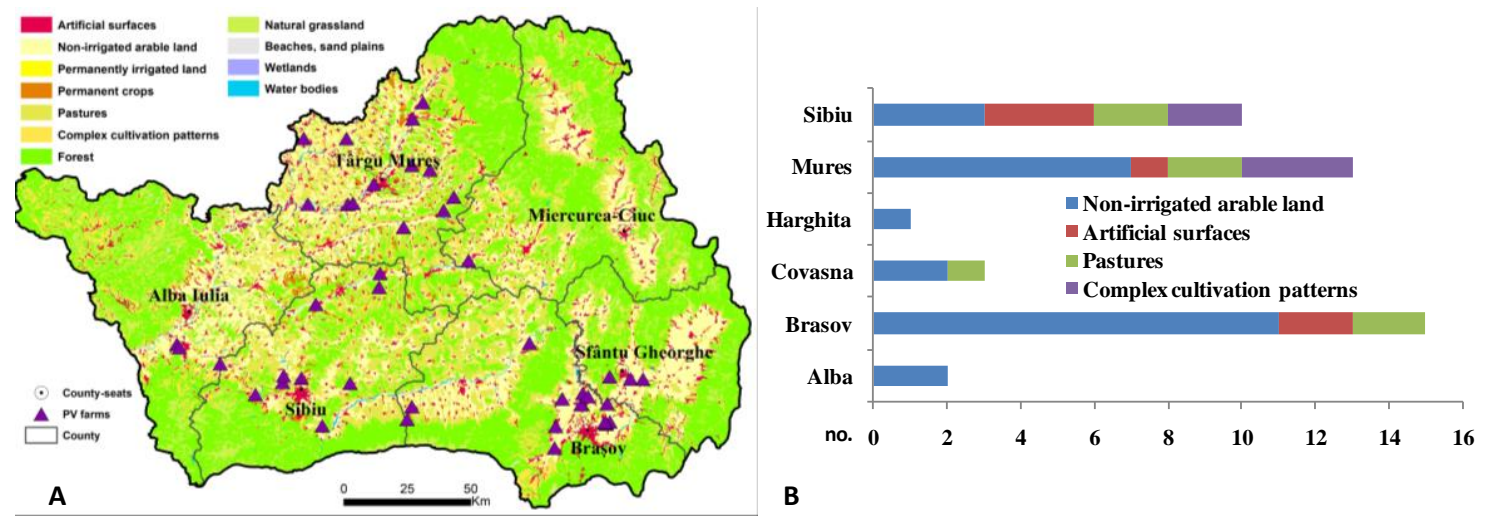

Figure 10. PV parks distribution on LUC categories in CDR (A) and at county level (B)

In Alba and Harghita Counties the three PV farms are set-up on non-irrigated arable land and the other $23 \mathrm{PV}$ farms from Brașov, Mureș and Covasna are set-up on valuable arable land with mollisoils (34.6\% of total non-irrigated arable land) and by other three soil categories in almost equal shares (e.g. cambisoils, clay-alluvial and hydromorphic soils, each with $11 \%$ to $15 \%$ of the total non-irrigated arable land). The six analyzed PV parks 
are located on three different LUC categories, i.e. non-irrigated arable land, artificial surfaces and pastures (Tab.1).

Table 1. The PV parks selected as case studies - LUC and setting-up year

\begin{tabular}{|c|c|c|c|}
\hline Case study rural LAU & County & LUC & Set-up year \\
\hline Miercurea Sibiului & Sibiu & Artificial surfaces & 2013 \\
\hline Ucea & Brașov & Pastures & 2013 \\
\hline Hoghiz & Brașov & Artificial surfaces & 2013 \\
\hline Halchiu & Brașov & Non-irrigated arable land & 2014 \\
\hline Cuci & Mureș & Non-irrigated arable land & 2014 \\
\hline Ernei & Mureș & Artificial surfaces & 2013 \\
\hline
\end{tabular}

National legislation is a key driving factor of the photovoltaic energy industry in Romania, also regulating the set-up of PV parks on different land use/cover categories [33]. The Government Emergency Ordinance no.57/2013 ${ }^{8}$ provisioned that, starting with 2014, the number of green certificates accredited to PV energy producers to be reduced, investors not being eligible to the support scheme if the PV parks are located on cultivable agricultural land. Thus, the PV parks located in Ucea, Mirecurea Sibiului, Hoghiz and Ernei were not affected by this legislative provision, while the other two PV farms selected as case studies were impacted by the cutting down of green certificates. In the selected case studies, the land used to hold the PV parks was bought from local farmers (e.g. Miercurea Sibiului, Hoghiz, Ernei) or granted from the mayoralties' available land (e.g. Ucea, Hăchiu, Cuci). It is important to mention that during field investigations, the information about the values of granted land and financial transactions were very difficult to obtain, probably because of the fact that generally the financial issues related to local economies are considered "delicate" topics. Only in Ucea, the interview has revealed that for 25 ha land covered by the PV parks 6,250 euro/ha/year is earned. Nevertheless, it can be estimated that those lands produce significant amounts of energy being covered by a high number of solar panels (e.g. 15,500 in Chirileu and 13,500 in Sângeorigiu de Pădure, both in Mures County). The installed power, which is related to the land used for the PV farms (for $1 \mathrm{MW}$ installed power, 2.4 ha are covered by solar panels), varies between 0.9 MW (Miheșu de Câmpie, Mureș County) and 55 MW in Ucea. As revealed by Fig. 11, the largest number of PV parks has an installed power ranging between $3 \mathrm{MW}$ and $5 \mathrm{MW}$.

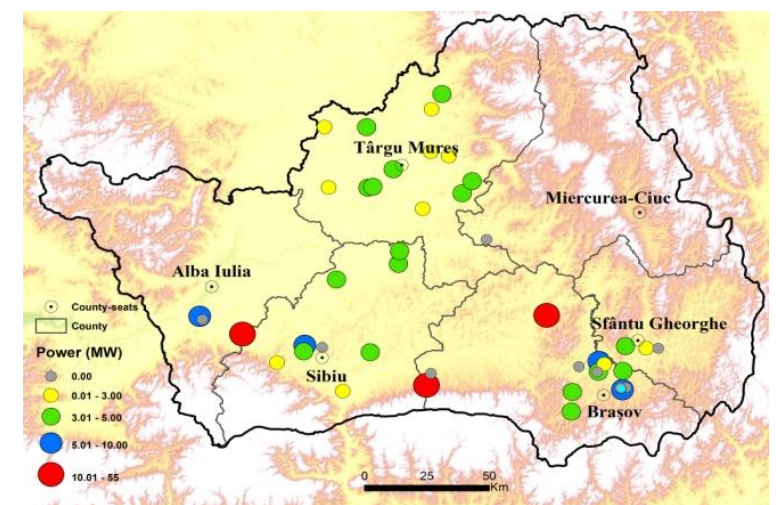

Figure 11. The installed power in photovoltaic farms located in CDR

\footnotetext{
${ }^{8}{ }^{1}$ Emergency Government Ordinance 2013. Internet: https://lege5.ro/ (14.1.2019)
} 
The issue of labour force employed for the implantation and function of a PV park is an important one, since green employment is one of the most important dimensions of the transition to the low-carbon economy. In this context, local studies on the employment of locals in activities related to green investments (i.e. PV parks) reveal the short-term positive impact in terms of small number of employees and low qualification. Thus, some aspects revealed by the field investigations are that most new created jobs had only a temporary character (during the construction of PV parks) and most of low-and mediumskilled jobs are taken by local community members. In Miercurea Sibiului, Hoghiz, Hălchiu and Cuci communes the interviews shown that during the operation of PV parks only one or two locals were employed, as guardians for park protection. Thus, at local level, the impact on labour employment is insignificant (e.g. in 2018, the total population employed in Ucea counted 228 persons and the unemployed persons were about 20, compared with only 2 workers employed for the guard of the PV farm protection).

The field investigations have also shown some positive impact of the initial investment in PV parks on the local budgets. Interviewing the local authorities from Ucea we found that taxes were perceived on land concession for the implementation of PV parks, on land sold to investors for implanting solar projects, on building licenses, tax on land, tax on special buildings and a special tax on the installed operation power of each solar project (Fig. 12).

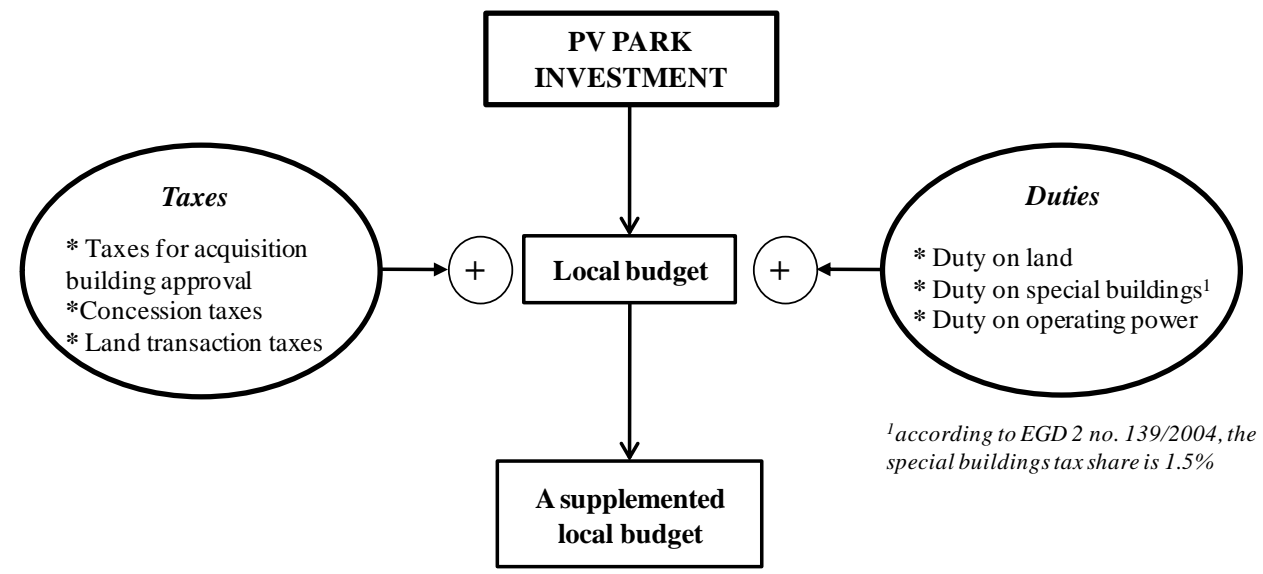

Figure 12. Investments in PV parks and the surplus to the local budgets

\section{CONCLUSIONS}

The rapid transformation and growth of the solar energy industry is a generous research topic. Studying and understanding the positive and negative impacts of PV farms on natural and socio-economic environments being essential to maximise the positive effects and preventing or/and minimising the potential negative consequences.

Overall, the general opinion on the setting-up of photovoltaic parks in the targeted six case studies is a positive one but it doesn't seem based on realistic and conscious information about both positive and negative effects. The local authorities and communities are very content with the implantation and operation of PV farms in their own settlements; however not being too sensitive to the visible negative effects (e.g. the loss of valuable arable lands) and to the potential future impacts on local natural and socio-economic environments. For instance, none of the interviewed local authorities bring up the existence of an action plan or strategy for the reintroduction in the agricultural circuit of the lands that are currently covered by the solar park installations, 
knowing that the lifetime of solar panels is about 25-30 years (on average), or even shorter according to [34].

In order to provide a general picture of the environmental and socio-economic impacts of PV parks in Centre Development Region, the authors computed a solar electric footprint to summarise the findings of the current study. According to [35,36], the solar electric footprint is defined as the land area required to supply all end-use electricity from solar photovoltaics, related to inhabitants. Thus, this indicator shows the direct relation between (1) the locals, who are supposed to be the first beneficiary of the solar energy produced by the PV parks located in a certain rural or urban settlement, and (2) the different category of land necessary to supply electricity from a PV park. As a result, this indicator could support the idea that for this type of renewable energy to be more environmentally friendly and more sustainable, the PV farms should be produced and consumed locally [37]. In the study area, the values of the solar electric footprint register values varying from $0.74 \mathrm{sqm} / \mathrm{inh}$. (Sfântu Gheorghe) to $534.3 \mathrm{sqm} / \mathrm{inh}$. (Ucea). The general analysis of CDR vs. the in-depth examination of each PV park reveal that, compared to the average solar electric footprint value of $8.9 \mathrm{sqm} / \mathrm{inh}$./entire study area (2018), individually, almost a half of PV parks had higher values. Some PV parks overcome the regional average to six times (e.g. Secuinei), thirteen times (e.g. Miercurea Sibiului) and fifty-one times (e.g. Ucea) (Fig. 13). Those photovoltaic farms are to large compared to the locals needs and to the true economic and environmental loss of arable land covered by the solar panels.

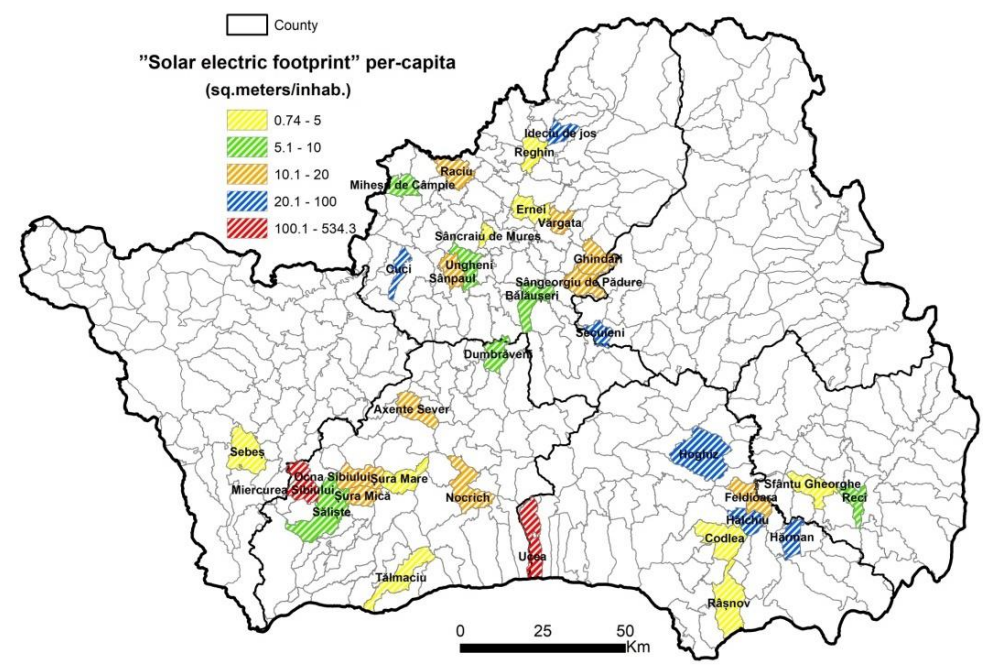

Figure 13. Distribution of solar electric footprint values in Centre Development Region

In Romania, Centre Development Region including, the development of photovoltaic energy industry through PV parks was a trend driven by the requirements of the national and EU policies and legislative provisions. However, the local analysis reveals some aspects that are hidden by the national studies and even by the regional ones. Thus, these too large surfaces covered by numerous photovoltaic farms are shown at their true dimension only by case-study and complex investigations, such as those approaching the environmental, social and economic aspects related to the setting-up of photovoltaic farms. 


\section{Acknowledgements:}

This work was supported by the project PN-III-P1-1.2-PCCDI-20170404/31PCCDI/2018 (UEFISCDI).

\section{REFERENCES}

[1] Bridge, G. Resource geographies 1. Making carbon economies, old and new. Progress in Human Geography 35-6. DOI: https://doi.org/10.1177/0309132510385524, 2011

[2] Bridge, G., Bouzarovski, S., Bradshaw, M., Eyre, N. Geographies of energy transition: Space, place and the low-carbon economy. Energy Policy 53. DOI: https://doi.org/10.1016/j.enpol.2012.10.066, 2013.

[3] Valodka, I., Valodkiene, G., (2015). The impact of renewable energy on the economy of Lithuania. Procedia 213, 123-128.

[4] Bilgili, F., Koçak, E., Bulut, Ü., The dynamic impact of renewable energy consumption on CO2 emissions: a revisited Environmental Kuznets Curve approach Renew. Sust. Energ. Rev. 54, 838-845, 2016

[5] Kaygusuz, K., Environmental impacts of the solar energy systems. Energy Sources Part A 31 (15), 1376-1386, 2009.

[6] Wanderer, T., Herle, S., Creating a spatial multi-criteria decision support system for energy related integrated environmental impact assessment. Environ. Impact Assess. 52, 2-8, 2015.

[7] Tsoutsos, T., Frantzeskaki, N., \& Gekas, V. Environmental impacts from the solar energy technologies. Energy policy, 33(3), 289-296, 2005.

[8] E.C., Externalities of Energy' Externe Project, DGXII, JOULE, Report No EUR 16520 EN, 1995

[9] E.C., Energy for the future: Renewable Sources of Energy. White Paper, European Commission, DG XVII, 1997

[10] Karapanagiotis N., Environmental impacts from the use of solar energy technologies. THERMIE, 2000

[11] Neff, T.L., The social cost of solar energy. A Study of Photovoltaic Energy Systems. Pergamon, New York, 1981.

[12] Dubey, S., Jadhav, N. Y., \& Zakirova, B., Socio-economic and environmental impacts of silicon based photovoltaic (PV) technologies. Energy Procedia, 33, 322-334, 2013

[13] Phillips, J., Determining the sustainability of large-scale photovoltaic solar power plants. Renew. Sust. Energ. Rev. 27, 435-444, 2013.

[14] Zanon, B., Verones, S., 2013. Climate change, urban energy and planning practices: italian experiences of innovation in land management tools. Land Use Policy 32, 343-355.

[15] Tsantopoulos, G., Arabatzis, G., Tampakis, S., Public attitudes towards photovoltaic developments: case study from Greece. Energ. Policy 71, 94-106, 2014.

[16] Heras-Saizarbitoria, I., Cilleruelob, E., Zamanillo, I., Public acceptance of re-newables and the media: an analysis of the Spanish PV solar experience. Renew. Sust. Energ. Rev. 15 (9), 46854696, 2011

[17] Nonhebel, S., Renewable energy and food supply: will there be enough land? Renew. Sust. Energ. Rev. 9, 191-201, 2005.

[18] Sliz-Szkliniarz, V.B., Assessment of the renewable energy-mix and land use trade-off at a regional level: a case study for the Kujawsko-Pomorskie. Land Use Policy 35, 257-270, 2013.

[19] Calvert, K., Mabee, W., More solar farms or more bioenergy crops? Mapping and assessing potential land-use conflicts among renewable energy technologies in eastern Ontario, Canada. Appl. Geogr. 56, 209-221, 2015.

[20] Sacchelli, S., Garegnani, G., Geri, F., Grilli, G., Paletto, A., Zambelli, P., Ciolli, D., Vettorato, D., Trade-off between photovoltaic systems installation and agricultural practices on arable lands: An environmental and socio-economic impact analysis for Italy. Land Use Policy, 56, 90-99, 2016. 
[21] Bădescu, V. Correlations to estimate monthly mean daily solar global irradiation: application to Romania. Energy, 24(10), 883-893, 1999.

[22] Paulescu, M., Dughir, C., Tulcan-Paulescu, E., Lascu, M., Gravila, P., \& Jurca, T., Solar radiation modeling and measurements in Timisoara, Romania: data and model quality. Environmental Engineering \& Management Journal (EEMJ), 9(8), 2010.

[23] Badescu, V., Gueymard, C. A., Cheval, S., Oprea, C., Baciu, M., Dumitrescu, A., Iacobescu F., Milos I., Rada, C., Accuracy analysis for fifty-four clear-sky solar radiation models using routine hourly global irradiance measurements in Romania. Renewable Energy, 55, 85-103, 2013.

[24] Alboteanu, I. L., Bulucea, C. A., \& Degeratu, S., Estimating solar irradiation absorbed by photovoltaic panels with low concentration located in Craiova, Romania. Sustainability, 7(3), 2644-2661, 2015

[25] de Sabata, C., Marcu, C., \& Luminosu, I. Some industrial utilization of solar energy in South West Romania. Renewable energy, 5(1-4), 387-389, 1994.

[26] Nichifor, M. A., Sustainable business models for wind and solar energy in Romania. Management \& Marketing, 10(1), 53-62, 2015.

[27] Iacobescu, F., \& Badescu, V., The potential of the local administration as driving force for the implementation of the National PV systems Strategy in Romania. Renewable energy, 38(1), 117-125, 2012.

[28] Grigorescu I., Vrînceanu A., Dumitrașcu M., Mocanu I., Dumitrică C., Mitrică B., Kuscicsa G., S,erban P., Regional differences in the distribution and environmental consequences of PV farms in southern Romania, Ukrainian Geographical Journal, vol. 3, 60-69, https://doi.org/10.15407/ugz2019.03.060, 2019.

[29] Vrînceanu, A., Grigorescu, I., Dumitrașcu, M., Mocanu, I., Dumitrică, C., Micu, D. Kucsicsa, G., Mitrică, B. Impacts of photovoltaic farms on the environment in the romanian plain. Energies, 12(13), 2533, 2019.

[30] Bălteanu, D., Mitrică, B., Mocanu, I., Sima, M., and Popescu, C., Caracterizarea geografică a regiunilor de dezvoltare. In: Bălteanu, D., Dumitraşcu, M., Geacu, S., Mitrică, B., Sima, M. (eds.), Romania. Natură și Societate. The Publishing House of the Romanian Academy, 621-652 (in Romanian), 2016.

[31] Soare, E. Durata de strălucire a Soarelui, in Clima României, Editura Academiei Române (Coord. Sandu I., Pescaru I., Poiană I., Geicu A., Cândea I., Țâștea D.), Editura Academiei Române, București, 105-114, 2008.

[32] Hernandez, R. R., Easter, S. B., Murphy-Mariscal, M. L., Maestre, F. T., Tavassoli, M., Allen, E. B., Barrows C.W., Belnap J., Ochoa-Hueso R., Ravi S., Allen, M. F., Environmental impacts of utility-scale solar energy, Renewable and sustainable energy reviews, 29, 766-779, 2014.

[33] Mocanu I., Mitrică B., Persu M., Socio-economic consequences of photovoltaic park implantation in Giurgiu County rural area (Romania), Acta geographica Slovenica, 59-1, 37-50, 2019.

[34] Fthenakis, V.M., Kim, H.C. \& Alsema, E., Emissions from Photovoltaic Life Cycles. Environ. Sci. Technol., 42, 2168-2174, 2008.

[35] Denholm P., Margolis R., The Regional Per-Capita Solar Electric Footprint for the United States, Technical Report NREL/TP-670-42463, National Renewable Energy Laboratory, http://www.nrel.gov/docs/fy08osti/42463.pdf, 2007

[36] Denholm, P., Margolis, R. M., Land-Use Requirements and the Per-Capita Solar Footprint for Photovoltaic Generation in the United States. Energy Policy, vol. 36, issue 9, United States. doi:10.1016/j.enpol.2008.05.035, 2008.

[37] Pelin, D., Šljivac, D., Topić, D., Varjú, V., Regional impacts of different photovoltaic systems. Pécs, 2014. 